\title{
THE DEVELOPMENT OF AFROCENTRICITY: A HISTORICAL SURVEY
}

\author{
DOI: http://dx.doi.org/10.17159/2223-0386/2016/n16a5 \\ Midas Chawane \\ Auckland Park Campus, University of Johannesburg \\ midasc@uj.ac.za
}

\section{Abstract}

The origin of the Afrocentric philosophy cannot be established with certainty. The most influential book advocating it was published in 1954. Marcus Garvey was one of the most influential propagators of the ideology. Afrocentricity as an idea and a philosophy gained momentum during the Civil Rights Movement in the United States of America. It was in the Temple University School of Scholars, frequently referred to as the Temple Circle, where the philosophy was institutionalised. The abstract noun "Afrocentricity" dates to the 1970s and was popularised by Asante during the 1980s, when he developed epistemological and methodological foundations for an Afrocentric curriculum based on an African perspective but aiming at global understanding. ${ }^{1}$

The approach proposes that blacks (at home and abroad) must look at knowledge from an African perspective. It suggests looking at matters at hand from an African viewpoint; that we misunderstand Africa when we use viewpoints and terms other than that of the African to study Africa. When Africans view themselves as centred and central in their own history, they see themselves as agents, actors, and participants rather than as marginal and on the periphery of political or economic experience. Although not the antithesis of Eurocentrism, Afrocentrism has become the most explosive and controversial subject, with both black and white scholars squaring off on its viability and non-viability. Mary Lefkowitz, Stanley Crouch, and Anthony Appiah are some of the main opponents of the Afrocentric idea. The Western dogma which contends that Greeks gave the world rationalism effectively marginalises those who are not European and becomes the leading cause of the disbelief about African achievements.

This paper traces the origin of Afrocentricity and describes the nature and propositions put forward by Afrocentrists that challenge the traditional Eurocentric perspective. This paper provides answers to the questions of why, when, where, and who were the main people behind its emergence. The paper also aims at outlining the main arguments why the approach should become part of academic debates. Afrocentricity, however, like other approaches, is not without pitfalls; for this reason the paper examines criticism levelled against it and responses thereto.

1 CC Verharen, "Molefi Asante and an Afrocentric curriculum”, The Western Journal of Black Studies, 24(4), 2000, pp. 223-238. 
Keywords: Afrocentricity; Eurocentricity; Africa; History; Ancient Egypt; Ancient Greece; Slavery; Colonialism; Racism.

\section{Introduction}

Since the advent of colonialism and the transatlantic slave trade, information on African history has been presented from a European point of view. This viewpoint sought to justify the colonisation of Africa and the enslavement of Africans during the transatlantic slave trade. This mission could be achieved by glorifying slavers and colonisers whilst at the same time distorting and neglecting African contributions to world development and their opinions. The liberation of Africa from European colonialism and the emancipation of slaves in the Americas came with calls for the liberation of knowledge by some Africans who proposed that knowledge should be looked at from the point of view of Africans. This approach came to be known as Afrocentricity within academic circles.

This paper offers a historical analysis of the development of the Afrocentric perspective to world knowledge. It aims at the exposition of the term "Afrocentricity" and traces the origin of the ideology, its development, and entry into academia as another facet of looking at the world. The paper also looks at the basic propositions put forward by Afrocentrists as opposed to the Eurocentric version that places Europeans at the centre and ignores contributions made by Africans towards world development. As a perspective, Afrocentricity is not without its critics. That is why attention is given to criticism levelled against it by both white and black opponents.

\section{Defining the concept of Afrocentricity}

The concept of Afrocentricity has been defined differently by various scholars. MK Asante defined Afrocentricity as a manner of thought and action in which the centrality of African interests, values, and perspectives predominate. He further stated that Afrocentricity is an exercise in knowledge and a new historical perspective. ${ }^{2}$ Another definition views Afrocentricity as an intellectual movement, a political view, and/or a historical evolution

2 MK Asante, Afrocentricity: The theory of social change (Chicago, Peoples Publishing Group, 2001), p. 3; JC Chukwuokolo, Afrocentrism or Eurocentrism: The dilemma of African development, New Journal of African Studies, 2009, p. 32. Asante is constantly acknowledged as the originator of the concept "Afrocentricity" and the one who introduced it as an academic concept. Other pioneers of the Afrocentric ideas include William Dubois, GGM James, Anta Diop, and Martin Bernal. 
that stresses the culture and achievements of Africans. ${ }^{3}$ The other definition believes that Afrocentricity is a transformation of attitudes, beliefs, values, and behaviour results, suggesting that it is the first and only reality for African people - a simple rediscovery. ${ }^{4}$ Another definition stresses the centrality of Africans and defines Afrocentricity as meaning "African centeredness", according to which Africans should be given their intellectual pride as the originators of civilisation. ${ }^{5}$ What is common with these definitions is that they all call for a change in the way that the world has been viewed, a change that should encompass all attributes of human existence, with emphasis on the centrality of African experiences.

As an academic exercise, Afrocentricity is defined in terms of the methodology, theory, and ideology that should be employed to achieve its objectives towards attaining the proposed change. Methodologically, Afrocentricity is intended as an answer to the intellectual colonialism that undergirds and serves to validate political and economic colonialism. In regards to theory, it places African people at the centre of any analysis of African phenomena in terms of action and behaviour. It is described as a devotion to the idea that what is in the best interest of African consciousness is at the heart of ethical behaviour and seeks to cherish the idea that "Africanness" itself is an ensemble of ethics. ${ }^{6}$ As an ideology it represents the continued longing among Africans for some set of ideas that would bind them together as a community and offer some alternative to an assimilation that is either excluded by Europeans or seen by Africans as an admission of inferiority and defeat. As an academic phenomenon, therefore, Afrocentricity serves the purpose of binding together the various elements of African and African-American studies, transforming them from an interdisciplinary assortment into a unified discipline, with ideological and intellectual goals, political purpose, and a set of commonly understood methods and theories. ${ }^{7}$

3 G Early, WJ Moses, L Wilson \& MR Lefkowitz, "Symposium: Historical roots of Afrocentrism", Academic Questions, 7(2), 1994, pp. 44-54.

4 WE Reed, EJ Lawson \& T Gibbs, "Afrocentrism in the 21 $1^{\text {st }}$ century", The Western Journal of Black Studies, 21(3), 1997, pp. 73-79.

5 JC Chukwuokolo, “Afrocentrism or Eurocentrism...", New Journal of African Studies, 2009, p. 32.

6 KW Stikkers, "An outline of methodological Afrocentrism, with particular application to the thought of W.E.B. DuBois", Journal of Speculative Philosophy, (22)1, 2008, pp. 40-49.

7 G Early, WJ Moses, L Wilson \& MR Lefkowitz, "Symposium: Historical roots of Afrocentrism", Academic Questions, 7(2), 1994, pp. 44-54. 


\section{The roots of Afrocentricity}

Although focusing on the African continent, Afrocentricity originated in the United States of America (USA). However, its origin and when it was first articulated cannot be established with certainty. There are several experiences that contributed to its emergence in the USA. The experiences of slaves in the Middle Passage during the transatlantic slave trade, the denial of education to slaves once they landed in the Americas, and the double cultures of Africanisms and Americanisms stimulated Afro-American hypersensitivity to culture and its relativity. ${ }^{8}$ The experience of double cultures resulted in some Afro-Americans rejecting Americanisation and starting to aspire to and explore African cultural practices. Thus, the experience of enslavement and racism in American society created the conditions for the emergence of the Afrocentric theory in the same sense that Marxist theory can be seen as a response to the economic constraints and oppression imposed on Russian peasants. ${ }^{?}$

In terms of its expression, Afrocentricity is not a new movement. The historical tendency of paying attention to Africa from an African perspective can be found in the USA in the early 1800s when it made one of its first appearances in an 1827 editorial in Freedom's Journal, the first black newspaper in the USA, which alleged a relationship between Africans and the ancient Egyptians. ${ }^{10}$ During the $20^{\text {th }}$ century, Frederick Douglass (1953) and David Walker (1996) attempted to explain the reasons for the abolition of slavery in part on the achievements of Nile Valley Africans. By tracing the existence of a magnificent ancient Egyptian civilisation in Africa, it demonstrated that European claims of African inferiority were false. ${ }^{11}$ Afrocentricity also has its roots in the great Afro-American tendency of seeking mental health through right living and right believing. Afrocentrists made the connection between black history and black education, properly construed, and black self-esteem, long before the word "self-esteem" was a "can't" word in the interpretation of African culture. ${ }^{12}$ Marcus Garvey, a PanAfricanist of Jamaican origin, is venerated by most Afrocentrists as one of the early Afrocentrists to claim that ancient Egypt gave to the world civilisation. ${ }^{13}$ The Afrocentricity idea gained momentum during the earlier forms of Black

8 CC Verharen, "Molefi Asante...”, The Western Journal of Black Studies, (24) 4, 2000, pp. 223-238.

9 JC Chukwuokolo, "Afrocentrism or Eurocentrism...”, New Journal of African Studies, 2009, p. 32.

10 G Early, WJ Moses, L Wilson \& MR Lefkowitz, "Symposium: Historical roots of Afrocentrism”, Academic Questions, 7(2), 1994, pp. 44-54.

11 CC Verharen, "Molefi Asante...”, The Western Journal of Black Studies. (24)4, 2000, pp. 223-238.

12 G Early, L Wilson, \& MR Lefkowitz, "Symposium: Historical roots of Afrocentrism”, Academic Questions, 7(2), 1994, pp. 44-54.

13 GF Will, "Intellectual segregation: Afrocentrism's many myths constitute condescension toward AfricanAmericans", News Week, 19 February 1996, p. 78. 
Nationalist thought - Negritude and Pan-Africanism - in the various forms it has taken since the $18^{\text {th }}$ century, the Black Power Movement of the 1960s and the Black is Beautiful Movement of the 1970s. ${ }^{14}$

Today, a growing cluster of Afrocentric scholars at major universities in the Americas - particularly in the USA - and Africa have established several professional associations and journals. The leading centre for the Afrocentric Movement is the Temple University School of Scholars, often referred to as the Temple Circle. The Temple University is regarded as the leading centre of Afrocentricity, probably because Asante (the proclaimed originator of the concept) is based there. Among the Temple Circle of Afrocentrists are scholars such as C. Tsehloane Keto, Kariamu Welsh Asante, Abu Abarry, Ama Mazama, Theophile Obenga, and Terry Kershaw. ${ }^{15}$

\section{The nature of Afrocentricity}

In terms of its aims and objectives, the Afrocentric movement comprises a series of activities by some concerned African and Afro-American scholars and educators directed towards achieving the particular end of ensuring that the African heritage and culture and its history and contribution to world civilisation and scholarship are reflected in the curricula on every level of academic instruction. Advocates of the Afrocentric ideas request a reconstruction and rewriting of the whole landscape of human history in its explanation of the origin of mankind, and the origin of philosophy, science, medicine, agriculture, and architecture. ${ }^{16}$

The nature of Afrocentricity is a subject of debate between adherents and opponents of the movement. In some academic circles, Afrocentricity is viewed as a theory just for the African diaspora. A common misconception related to the concrete objectives of Afrocentricity is that Afrocentrists are antiwhite. This, according to Afrocentrists, is not true and instead they maintain that it is anti-oppression. They cite this as a reason why Afrocentricity has been resentfully received by the academy as a hostile takeover rather than a movement to construct space for the study and criticism of Africans. ${ }^{17}$

14 G Early, WJ Moses, L Wilson, \& MR Lefkowitz, "Symposium: Historical roots of Afrocentrism”, Academic Questions, 7(2), 1994, pp. 44-54.

15 CC Verharen, “Molefi Asante...", The Western Journal of Black Studies, (24)4, 2000, pp. 223-238.

16 JC Chukwuokolo, "Afrocentrism or Eurocentrism...", New Journal of African Studies, 2009, p. 32.

17 RL Jackson 1l, "Afrocentricity as metatheory: A dialogic exploration of its principles", RL Jackson \& EB Richardson (eds.), Understanding African American rhetoric: Classical origins to contemporary innovations (New 
Afrocentricity has been labelled as an antithesis, a defensive counter-move against Eurocentricity seeking to replace the European view of the world. Adherents maintain that it cannot be the antithesis of Eurocentricity and reject the notion of it seeking to replace Eurocentricity. In the words of Pavan Varma, "the aim of Afrocentricity is not reselecting the bars in order to form new divides" ${ }^{18}$ Chukwuokolo supported this when he stated that: ${ }^{19}$

Afrocentrism, which means African centeredness, does not violently confront any person or people, but is a resolute attempt to put the records right. It is about placing African people within their own historical framework. It is a demand that the contributions of Africans in all areas of civilization be reflected in world history.

Asante added weight to this contention by saying that Afrocentricity is only one of several cultural perspectives from which multiculturalism in education is derived, noting that Afrocentricity is not the opposite of Eurocentricity, nor does it seek to replace Eurocentricity. According to him, Afrocentricity is constructive primarily because it does not deny others their place. It is based on harmonious coexistence of an endless variety of cultures. Equally, there can be no true multiculturalism without Afrocentrism. ${ }^{20}$ Afrocentricity does not deny "the right of Europe to view the world from its cultural centre". The gist of the argument by Afrocentrists is that the European view must not be imposed as universal. Just as much as Europeans, Africans are entitled to give their own perspective on the African experience, making Afrocentricity an exercise in self-knowledge. Afrocentricity becomes valuable also for Europeans by giving them a new perspective, an ability to see from different angles and by so doing, putting them in a position to explore different views and bring new perspectives. ${ }^{21}$ Afrocentricity is not the opposite of Afrocentricity but a particular perspective for analysis. Consequently, it becomes necessary to examine all data from the standpoint of Africans as subjects and human agents, rather than as objects in a European frame of reference.

The impression that Afrocentricity seeks to replace Eurocentricity is based on the suggestion that in dealing with ancient history, Afrocentrists have replaced white Greeks with black Egyptians. Afrocentricity does not deny other cultures

York, Routledge, 2003), pp. 115-129.

18 P Varma, "Decolonising universities conference", University of Cincinnati (available at https://www.youtube.

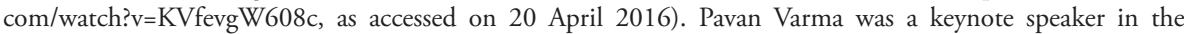
conference: Decolonising Universities.

19 JC Chukwuokolo, "Afrocentrism or Eurocentrism...", New Journal of African Studies, 2009, p. 33.

20 A Boyd \& CJ Lenix-Hooker, "Afrocentricism: Hype or history", Library Journal, (117)18, 1 November 1992, pp. 46-49.

21 MK Asante, Afrocentricity: The theory of social change..., p. 3. 
standing on their own ground. The Greeks can remain firmly in control of whatever cultural legacy they bring to the world. What Afrocentrists firmly believe is that it is important to demonstrate that ancient Egyptians must be seen in the correct light, which is that ancient Egypt was before ancient Greece as ancient Greece was before Rome. In this way, the Greeks are left in their place and uncovered the Egyptians in theirs. The fact of the matter is that history written from the Eurocentric perspective discounts and twists the substantial evidence of African influence on Greece by overlooking ancient writings of Aetius, Strabo, Plato, Homer, Herodotus, Diogenes, Plutarch, and Diodorus Siculus. The observation made by Aristotle, who reported that the Egyptians gave the world the study of geometry and mathematics, serves as more proof of the contribution of Africa to the world. ${ }^{22}$ Afrocentrist scholars challenge the Western view which contends that Greeks gave the world rationalism, thereby effectively marginalising those who are not European and becomes the leading cause of the disbelief about African achievements. ${ }^{23}$

The fact that Afrocentricity originated in the USA led to the understanding by some scholars that it is a theory not for Africans in Africa but for AfroAmericans, an assertion that is rejected by Afrocentrists. For adherents of this ideology, Afrocentricity is not a theory just for the African diaspora, but for Africans at home as well. Their argument is that Afrocentricity is primarily rooted on the continent of Africa where it has its largest following, which makes it a theory for Africans in Africa as well. They support this line of argument by claiming that the heroes of the Afrocentric movement are found both in the diaspora and in Africa and are too numerous to mention. Besides, the history of Afro-Americans and that of Africans is intertwined. ${ }^{24}$ Their history is intertwined because of their African origin, colour, and, most importantly, a common history of oppression. As much as the history of Africans in the Americas started in Africa, the general history of Africa can never be complete without the transatlantic slave trade. In addition, there is always a sense of solidarity and constant search by some people of African origin for a common historical mission, for the elements that bind them together as a group, other than a common history of oppression. These elements include the Black Consciousness, Black Power, and Black is Beautiful movements. The relations between Africans in Africa and Afro-Americans were cemented by DuBois,

22 MK Asante, "Afrocentricity and its critics. A quick reading of rhetorical Jingoism: Anthony Appiah and his fallacies", 2009 (available at http://science.jrank.org/pages/8216/Afrocentricity-Afrocentricity-Its-Critics.html, as accessed on 2 April 2016).

23 MK Asante, Afrocentricity: The theory of social change..., p. 3.

24 CC Verharen, Molefi Asante..., The Western Journal of Black Studies, (24)4, 2000, pp. 223-238. 
who once stated that: ${ }^{25}$

... he speaks first and foremost as a son of Africa and calls to Africa, Egypt, and Ethiopia and the need for Afro-Americans to see their thinking, self-understanding, and intellectual efforts to be related to those of Africans.

Because Afrocentricity's emergence is concomitant with the historical and cultural context of Africans seeking to assert themselves, it is consistent with the interpretative life of the African person. It requires Africans to see themselves through their own perspective, because neither the Chinese nor the Europeans view phenomena from the perspective of the African, and they should not. For Asante, Afrocentricity deals with the question of African identity from the perspective of African people as centred, located, oriented, and grounded. The primary argument here is that Africans have been dislocated and decentred and as a result see the world from the European perspective. Afrocentricity endeavours to relocate and centre the African person as an agent in human history in an effort to eliminate the illusion of the peripheries. ${ }^{26}$ In support of Asante, Kwame Ture emphasised that the coloniser sought to change the colonised in every respect except colour by moving them off of their psychological, political, fashion, philosophical, historical, name, linguistic, and cultural terms. As it is, Africans are operating in terms laid down during the European intervention of over 500 years. Afrocentricity thus endeavours to correct this and empower Africans to operate on their own terms, thereby making them agents or actors in their history. ${ }^{27}$

Unlike the Eurocentric view that tends to take an ethnocentric view posing as a universal view, Afrocentricity allows other cultures to view history from their own perspective. What Afrocentricity does is to provide a counterforce to the prevailing intellectual colonialism that focuses discriminatorily on European influences and traditions in interpretations of African thinkers, which rigorously brackets them. ${ }^{28}$ In the standard Western view, neither the Africans nor the Chinese had rational thinking. ${ }^{29}$ Thus, the Afrocentrists reject the Eurocentric view that has become an ethnocentric view which elevates the European experience and downgrades all others, and reinforces the coloniser's

25 MK Asante, "Afrocentricity and its critics..." (available at http://science.jrank.org/pages/8216/AfrocentricityAfrocentricity-Its-Critics.html, as accessed on 2 April 2016).

26 MK Asante, Afrocentricity: The theory of social change..., p. 4.

27 Kwame Ture vs Molefi Asante, Africa and the future debate (Pan Africanism vs Afrocentrism) (University of Cincinnati, 2 February 1996) (available at http://thekidsmagic.com/watch/o3zolaSp0Kk/kwame-ture-vsmolefi-asante-africa-and-the-future-debate-pan-africanism-vs-afrocentrism, as accessed on $12 \mathrm{March}$ 2016).

28 KW Stikkers, "An outline of methodological Afrocentrism, with particular application to the thought of W. E. B. DuBois", Journal of Speculative Philosophy, (22)1, 2008, pp. 40-49.

29 A Boyd \& CJ Lenix-Hooker, Afrocentricism...", Library Journal, (117)18, 1 November 1992, pp. 46-49. 
worldview and rationality as the only universally valid ones. For Afrocentrists, the idea that human progress has only come from white people and not the entirety of the human race needs to be corrected. Afrocentricity maintains that any group that has no story is abandoned to others that do; that the group's members dismiss their people or themselves as not being achievers or even participants in world history. Afrocentricity should take its place not above but alongside other cultural and historical perspectives and calls on Africans to be engaged in examining all aspects of their world. ${ }^{30}$ In this way, Africans can come to full self-determination and achieve full humanity and mentally position themselves to overthrow and denounce a Eurocentric hegemony, empower them to comprehend that truth is conventional, and that Africans are capable of forming their own truth to suit their own political and social purposes. ${ }^{31}$

\section{Main arguments}

Afrocentricity does provide the theoretical basis on which knowledge should be grounded, especially in the humanities and social sciences where it can provide a new perspective. Although there are many themes that need consideration from the Afrocentric perspective, there are certain topics that need urgent attention and these are, amongst others, the contribution of ancient Africa and Africans to world civilisation, colonialism, slavery, racism, and the reinterpretation of African history.

\section{Afrocentricity and ancient civilisations}

Afrocentrists believe that the study of Africa and African people, wherever they live or have lived, necessitates distinct approaches because so much of their civilisations were intentionally destroyed or distorted by invaders, interrupted by the transatlantic slave trade, or not written or codified. Furthermore, they generally maintain that for decades much Western scholarship was subverted by racism and cultural arrogance. ${ }^{32}$ The starting point for colonisers was to paint Africans as uncivilised people with no history. In order to placate this idea, they downplayed any achievements made by ancient Africans. Arguments that ancient Egyptians were not black Africans and that the Great Zimbabwe

30 A Boyd \& CJ Lenix-Hooker, “Afrocentricism...”, Library Journal, (117)18, 1 November 1992, pp. 46-49.

31 G Early, WJ Moses, L Wilson \& MR Lefkowitz, "Symposium: Historical roots of Afrocentrism", Academic Questions, 7(2), 1994, pp. 44-54.

32 A Boyd \& CJ Lenix-Hooker, “Afrocentricism...”, Library Journal, (117)18, 1 November 1992, pp. $46-49$. 
walls and the pyramids were not built by Africans need to be challenged. Africa's influence on ancient Greece, the oldest European civilisation, was profound and significant in art, architecture, astronomy, medicine, geometry, mathematics, law, politics, and religion. Yet there has been a furious campaign to discredit African influence. To support this, Afrocentrists point to a number of books and articles seeking to prove the Egyptian influence on Greece. ${ }^{33}$

For Afrocentrists, the achievements of Africans in ancient times were well documented by Herodotus (considered the father of history in a Eurocentric world) who glorified the achievements of Egypt in relationship to Greece. Aristotle reported that the Egyptians gave the world the study of geometry and mathematics. Apart from Herodotus and Aristotle, other Greek historians who wrote about what the Greeks learned from Egypt are Homer, Lamblicus, Aetius, Diodorus Siculus, Diogenes Laertius, Plutarch, and Plato. Although without proof in some cases, some Afrocentrists argue that ancient records show that some ancient Greek students who studied in Egypt include Plato, Solon, Lycurgus, Democritus, Anaxamander, Anaxagoras, Homer, Thales, Pythagoras, Eudoxus, and Isocrates. ${ }^{34}$

In an attempt to prove the contribution made by Africans to world civilisation, Ivan Van Sertima, an African Studies professor at Rutgers University, has become skilled in many disciplines, including the study of metals, plant life, and mapmaking, to help him pursue the truth about African civilisations. Van Sertima asserted and provided both physical and historical proof that Africans were in the Americas long before Columbus' journeys. He believed that some academic circles have accepted, without question, the Eurocentric view of history that makes no mention of this. ${ }^{35}$

It was this view of Europeans of seeing Africans as having made no contribution to world civilisation as a people with no history that was used as a pretext to colonise and enslave Africans.

\section{On slavery and colonialism}

Afrocentrists argue that when colonising and enslaving Africans, European colonisers imagined and projected themselves as the liberators of savages, freeing them from their unreason by placing them under the rule of the one true and

33 MK Asante, "Afrocentricity and its critics..." (available at http://science.jrank.org/pages/8216/AfrocentricityAfrocentricity-Its-Critics.html, as accessed on 2 April 2016).

34 MK Asante, Afrocentricity: The theory of social change..., p. 6.

35 CC Verharen, Molefi Asante..., The Western Journal of Black Studies, (24)4, 2000, pp. 223-238. 
universally valid reason; downplaying economic benefits resulting from these endeavours. For them, Africa had no history prior to their arrival, a kind of thinking which reflected Hegel's pronouncement regarding Africa that: ${ }^{36}$

Africa... is no historical part of the World; it has no movement or development to exhibit. ... What we properly understand by Africa, is the Unhistorical, Undeveloped Spirit, still involved in the conditions of mere nature.

They (colonisers and slavers) worked under the delusion that their practices were rooted largely in the assumption of a universal reason; anything contrary to this way of thinking, such as protests and slave revolts, were taken merely as evidence of their erroneous views and undeveloped rationality and that the colonised and slaves simply did not understand. ${ }^{37}$

Colonial powers and slave masters thus considered themselves not as oppressors but as saviours, transforming the presumably irrational, lazy, inefficient, unproductive darker races into efficient instruments of rational economic production and saw their endeavours not as conquest and control but as bearers of the white man's burden to civilise the barbarians. In their attempt to achieve their colonial goals, colonisers cared little about understanding the culture of Africans prior to making their sweeping pronouncements. ${ }^{38}$

The success of colonisation and slavery was not physical subjugation, but the colonisation of the mind and the fostering of slave mentality in Africans. Little or no analyses have been done in the field of colonisation of the mind and its impact on the lives and way of thinking of Africans. In short, the arenas of culture, education, and ideas before, during, and after colonialism and slavery need proper analyses. ${ }^{39}$

There is a need to understand the progression inherent in colonialism and slavery that created the colonisation of the mind. The first move adopted by the coloniser and slave masters was the condemnation and destruction of the culture of the colonised and slaves and by so doing, laying the grounds for their "civilising mission". Imperial powers could not impose their culture without denunciating African culture. In order to keep Africans in a perpetual state of servitude, decent education was made difficult to access for the

36 G Early, WJ Moses, L Wilson, and MR Lefkowitz, "Symposium: Historical roots of Afrocentrism", Academic Questions, 7(2), 1994, pp. 44-54.

37 MK Asante, "Afrocentricity and its critics..." (available at http://science.jrank.org/pages/8216/AfrocentricityAfrocentricity-Its-Critics.html as accessed on 02 April 2016).

38 G Early, WJ Moses, L Wilson \& MR Lefkowitz, "Symposium: Historical roots of Afrocentrism", Academic Questions, 7(2), 1994, pp. 44-54.

39 P Varma, "Decolonising universities conference", University of Cincinnati (available at https://www.youtube. com/watch?v=KVfevg W608c), as accessed on 20 April 2016. 
Africans; whilst for those who could access it, the type of education provided was meant to produce an efficient, proficient, and subservient person - to create a class of capitalists to serve as a link between colonisers and the ruled. This gutter education channelled Africans to a working class status since it was designed to produce interpreters of policy but not policy makers and came to be characterised by rote learning with emphasis on exam and not independent thinkers. ${ }^{40}$

Colonisation of the mind could not succeed without taking away the language and names of the ruled and replacing them with those of the ruler. Among the conditions of colonialism and slavery was that the colonised was to speak, if they were allowed to do so publicly, in the language and through the theoretical agenda of the coloniser and thereby validating the coloniser's intellectual conception of the world. In this process of speaking publicly, the colonised were expected to flatter their masters and simultaneously denigrate their African cultural traditions.

African students studying at universities built by the colonial powers based on European models were required to learn in the colonisers' languages and to master the texts of the European canon. Any attempt to articulate one's own native wisdom or tradition, if it was allowed at all, had to be by reference to European concepts, thinkers, and texts and always, of course, still in the colonisers' language. ${ }^{41}$ In order to decolonise the mind, Afrocentrists suggest the liberation of all universities from the curriculum dominated by European knowledge. This is despite some achievements made in the past 25 years or so; for example, the study of African history has undergone a transformation and continues to do so as there are talks today about the decolonisation of African history. ${ }^{42}$ According to Afrocentrists, there is no African university in Africa but only copies of European universities. An African university should be one that starts from the beginning, which means the rebuilding of the entire university with chronology as a starting point. Students at these rebuilt universities should know that Nubia and Kemet (African name for Egypt, which is a Greek name) are to Africa what India and China are to Asia or Greece and Rome to Europe.

40 CC Verharen, Molefi Asante..., The Western Journal of Black Studies, (24)4, 2000, pp. 223-238.

41 G Early, WJ Moses, L Wilson \& MR Lefkowitz, "Symposium: Historical roots of Afrocentrism”, Academic Questions, 7(2), 1994, pp. 44-54.

42 J de Villiers, "The discipline of history and the new South Africa - Should South African history be re-written?", Tydskrif vir Geesteswetenskappe, 52(2), June 2012, pp. 196-208. 
Eurocentricity, according to Afrocentrists, teaches that universities started with Greece some 1000 years $\mathrm{BC}$, without considering the fact that the pyramids were built in $5000 \mathrm{BC}$. For them the first appearance of Greece was in $1000 \mathrm{BC}$ and it started with Homer, long after the period of the pyramids in Egypt. Another myth perpetuated by Eurocentricity, according to Afrocentrists, is that there was never any writing by Africans, whilst there has been Nubian, Kemet, and Axum writing which is not emphasised by the Eurocentric view. The argument by Afrocentrists is that Greek philosophy is based directly on an "Egyptian Mystery System", which was copied by Greek philosophers who studied in Egypt and also African philosophers who lived before Ancient Greece. ${ }^{43}$ Pythagoras, they claim, went to Thieles and asked him to teach him what he knew about philosophy. He said to him to do what he himself did, to go to Egypt and learn there. Further proof of Egypt's glory was the writings of Herodotus in $5 \mathrm{BC}$, who wrote about the splendour of Egypt. This led some Afrocentrists to believe that what is called the Greek civilisation was in fact stolen from Egypt when Aristotle acquired his philosophy by plundering the Great Library of Alexandria. ${ }^{44}$

\section{On racism}

Another aspect of African history that needs to receive special attention according to Afrocentrists is how the subject of race or racism has been tackled by Eurocentrists. According to Kwame Ture, Africa is constantly undermined because of racism and as being seen to have made no contribution to the world. ${ }^{45}$ Although the concept of race is more recent, Afrocentrists argue that the racist line of thinking has its roots in the $15^{\text {th }}$ century, with each century since then having seen its share of Eurocentric self-serving ways in terms of interpretation of history. ${ }^{46}$ Afrocentrists maintain that it was during the era of colonialism and transatlantic slave trade that racism was invented as a ploy to oppress and exterminate Africans, a counter-assertion to the Eurocentric view that sees racism as naturally endowed as proposed by scientific racism. It is for this reason that Afrocentrists see race as central to the study of African history, by pointing out that it has been and still is an issue in African historiography.

43 G Early, WJ Moses, L Wilson \& MR Lefkowitz, "Symposium: Historical roots of Afrocentrism”, Academic Questions, 7(2), 1994, pp. 44-54.

44 GF Will, "Intellectual segregation: Afrocentrism's many myths constitute condescension toward AfricanAmericans", Newsweek, 19 February 1996, p. 78.

45 Kwame Ture vs Molefi Asante, "Africa and the future debate...", University of Cincinnati, 2 February, 1996, (available at http://thekidsmagic.com/watch/o3zoIaSp0Kk/kwame-ture-vs-molefi-asante-africa-and-the-futuredebate-pan-africanism-vs-afrocentrism, as accessed on 12 March 2016).

46 MK Asante, Afrocentricity: The theory of social change..., p. 6. 
Barthold Niebuhr, historian of Ancient Rome, supported this when he commented on the racist manifesto in history: ${ }^{47}$

Race is one of the most important elements of history still remaining to be examined that which is, in truth, the very first basis upon which all history is reared and the first principle upon which it must proceed.

WEB Du Bois asserted that the problem of the $20^{\text {th }}$ century is the problem of the colour line. His observation almost 100 years ago is still appropriate for both the USA and South Africa as we move forward. It should be noted that contrary to the European view that race is a natural phenomenon; Afrocentrists uphold the view that the concept "black" (meaning race) is not an African concept, but that it was created outside Africa, mainly by Europeans. For example, when talking about ancient Sudan, the land of the blacks, colour is not important. It is a descriptive term, relative to Europe, not a derogatory one. Similarly, when one refers to Ethiopians as people with painted faces, it is using a descriptive term. ${ }^{48}$

Related to racism is scientific racism, which was employed as a tool to justify slavery and colonialism. During the $18^{\text {th }}$ century in the Netherlands, Peter Campier, a notorious racist, compared facial and skull measurements of blacks and monkeys and developed a hierarchy in which he said that the Greek statuary was the highest form and the lowest was the Negro. ${ }^{49}$ Another example is that of the former American president, Thomas Jefferson, who wrote: ${ }^{50}$

This unfortunate difference of colour and perhaps of faculty is a powerful obstacle to the emancipation of these people... I advance it therefore as a suspicion only that the blacks whether originally a distinct race or made distinct by time and circumstances, are inferior to the whites in the endowments of the mind and body.

The racist ideology was formed and spread by clusters of clergymen, philosophers, physicians, and professors who lived on the salaries of churches and universities. It was politicians, intellectuals, and slave owners (in the Americas) who implemented the white supremacy theories. ${ }^{51}$

47 G Early, WJ Moses, L Wilson \& MR Lefkowitz, "Symposium: Historical roots of Afrocentrism”, Academic Questions, 7(2), 1994, pp. 44-54.

48 MK Asante, Afrocentricity: The theory of social change, p. 5.

49 G Early, WJ Moses, L Wilson \& MR Lefkowitz, "Symposium: Historical roots of Afrocentrism", Academic Questions, 7(2), 1994, pp. 44-54.

50 MK Asante, Afrocentricity: The theory of social change..., p. 6.

51 G Early, WJ Moses, L Wilson \& MR Lefkowitz, "Symposium: Historical roots of Afrocentrism", Academic Questions, 7(2), 1994, pp. 44-54. 


\section{Perspective on African history}

Afrocentrists believe that the study of Africa and African people necessitates distinct approaches because so much of their civilisation was intentionally destroyed by invaders, interrupted by the slave trade, or not written or codified. Furthermore, they generally maintain that for decades much Western scholarship was subverted by racism and cultural arrogance. ${ }^{52}$ Kwame Ture argued that Africans were going through a similar process of development of continental unity that was taking place in Europe and Asia when they were interrupted by the transatlantic slave trade and colonialism. For Afrocentrists, it was the Berlin Conference of 1884-1885 that interrupted the process of continental unity in Africa by dividing the continent into various colonist spheres of control. The division of Africa made it difficult for Africans and Africa to unite..$^{53}$

From the Afrocentric perspective, history is considered to be rooted in the acknowledgement that there is an African or non-white (or non-Western) view of the world and of African history that has been suppressed and distorted by the Western world in order to support white supremacy. History, according to Afrocentricity, must reopen the discussion on everything from race theory, ancient civilisations, colonial and post-colonial, African and European personalities, and dislocation in the writing of African authors, both at home and in the diaspora. Afrocentrists should examine these topics with the perspective of African people as subjects and not objects of historical experiences. ${ }^{54}$ Advocates of the Afrocentric idea propose the notion of multiplication of cultural perspectives that must entail the reconstruction of post-colonial African cultures through a synthesis of both African and European contributions to humanity. ${ }^{55}$

The other two main important themes in the history of Africa that need revisiting are the transatlantic slave trade and colonialism. As stated, the Eurocentric version of the two undertakings was to civilise Africans, who in their eyes were backward. The Afrocentric version purports that the main purpose of colonialism and the transatlantic slave trade was to enrich Europe and white America. It is therefore of importance to study how the two continents benefitted from these two undertakings. ${ }^{56}$

52 A Boyd \& CJ Lenix-Hooker, "Afrocentricism...", Library Journal, (117)18, November 1992, pp. 46-49.

53 Kwame Ture vs Molefi Asante, "Africa and the future debate...", University of Cincinnati, 2 February 1996 (available at http://thekidsmagic.com/watch/o3zolaSp0Kk/kwame-ture-vs-molefi-asante-africa-and-the-futuredebate-pan-africanism-vs-afrocentrism, as accessed on 12 March 2016).

54 MK Asante, Afrocentricity: The theory of social change..., p. 6.

55 CC Verharen, "Molefi Asante...", The Western Journal of Black Studies, (24)4, 2000, pp. 223-238.

56 Anon., "What scientific racism did to the Blacks world wide", BBC Documentary (available at https://www. youtube.com/watch?v=3f1_VcVWpkI, as accessed on 20 April 2016). 
Schools must teach a world history that does not only preach contributions made by Europeans in the advances the world has made but the contributions of the non-white people of the world as well. The idea that human progress has only come from the Europeans and not the entirety of the human race must be reconsidered. The University of Timbuktu, for example, is one of the world's first universities. In the $14^{\text {th }}$ century, it facilitated more than 25 000 students, which also made it the world's biggest university. The claim is supported by the establishment of the archival repository (destroyed in 2015 during the Civil War in Mali) meant to store documents relating to the activities of the University of Timbuktu. ${ }^{57}$ Another example that needs historical consideration is the Ghana Empire that lasted for 1500 years from 200 BC to 1240 when Sundiate of Mali defeated Sumanguru (Ghana). ${ }^{58}$ These things, Afrocentrists claim, are not given due attention because they exhibit African glory that the Eurocentric approach downplays. ${ }^{59}$

With regard to post-colonial African history, Afrocentrists calls for change of what was inherited from colonialism; stating, for example, that Africa cannot always navigate between the failed European economic systems of capitalism and socialism, which are foreign. They lament that after independence, Africa had enough chance to figure out a suitable economic system that will be better suited for her. In this case, they consider strategy to be better than strength and that Afrocentricity is a proper strategy. ${ }^{60}$

\section{Criticism of Afrocentricity}

Scholars, both black and white, have squared off on this issue of whether Afrocentricity aims to balance or distort history, which caused Afrocentricity to become the most explosive and controversial subject to be embraced by African scholars. Afrocentricity has provoked much controversy and was harshly attacked by many Eurocentric scholars and critics such as Diane Ravitch, Arthur Schlesinger, George Will, and Mary Lefkowitz. These critics proclaimed that Afrocentricity posed a threat to the supposed unity among US citizens. However, Afrocentricity has also had its critics among black progressives, feminists, and

57 K Dlanga, "\#PretoriaGirlsHigh and the myth of multiculturalism”, News 24, 26 August 2016.

58 Kwame Ture vs Molefi Asante, “Africa and the future debate...”, University of Cincinnati, 2 February, 1996 (available at http://thekidsmagic.com/watch/o3zoIaSp0Kk/kwame-ture-vs-molefi-asante-africa-and-the-futuredebate-pan-africanism-vs-afrocentrism, as accessed on 12 March 2016).

59 K Dlanga, “\#PretoriaGirlsHigh and the myth of multiculturalism”, News 24, 26 August 2016.

60 Kwame Ture vs Molefi Asante, "Africa and the future debate...”, University of Cincinnati, 2 February, 1996, (available at http://thekidsmagic.com/watch/o3zoIaSp0Kk/kwame-ture-vs-molefi-asante-africa-and-thefuture-debate-pan-africanism-vs-afrocentrism, as accessed on 12 March 2016). 
humanists. ${ }^{61}$ Major black feminist critics have included Patricia Hill Collins. Some of these academics also challenge those scholars who not only affirmed the achievements of black African civilisations but also placed Africa at the centre of history and culture and claimed that European culture emerged from Africa. ${ }^{62}$

One of the most recent works in opposition is the book Not out of Africa by professor Mary Lefkowitz. In this book she seeks to reaffirm the impression that Greece did not receive substantial contributions from Kemet (Egypt). Lefkowitz argues that an Afrocentric curriculum is a tissue of myths naively designed to bolster African-American self-esteem. ${ }^{63}$ Afrocentricity is also attacked for being something of a cultural phenomenon. These critics' argument is that many of the discipline's findings are arrived at in unscholarly fashion, noting that the academic credentials of many Afrocentrists are in fields other than African studies. In order to establish the validity of the findings of Afrocentric scholarship, they continue to challenge the route taken by these scholars and call for a need to examine this route. ${ }^{64}$ Some critics see Afrocentricity as a form of fragmentation, desegregation, and tribalisation of American life standing, as opposed to the ideal of multiculturalism. These critics contend that the Afrocentric curriculum removes blacks from America in favour of a fictitious connection with Africa; that many black American families have been in this country for a long time and that the whole view that they are part of the African culture is ridiculous. ${ }^{65}$

Other opponents of Afrocentricity assert that the movement is based on powerplay, where politicians pose in academic gowns. Other critics see Afrocentricity as millenarian in nature; a utopia romanticising the past, rather than in a chiliastic future. Those who convert to Afrocentricity often change their names, as a sign that they have put a new man in the place of the old man, asserting that: ${ }^{66}$

Afrocentrists are like the people who come knocking on your door to present you with the good news, the truth, and the real truth. You cannot argue with them, because they are convinced that you are the one who is confused.

61 NR Allen, "The problem with Afrocentricity: Part 1", A book review: An Afrocentric manifesto by Molefe Kete Asente, Polity Press, 2007, p. 1.

62 MK Asante, "Decolonising universities", TV multiversity (available at https://www.youtube.com/ watch?v=S8gZT6Vc9pk, as accessed on 10 March 2016).

63 M Lefkowitz, Not out of Africa: How "Afrocentricism" became an excuse to teach myth as history (United States of America, Basic Books, 1997), p. 3.

64 J Elson, "Attacking Afrocentrism: A classics scholar sharply challenges the emerging theory that ancient Greece "stole" its best ideas from ancient Egypt", Time, 19 February, 1996.

65 MK Asante, "Decolonising Universities" (available at https://www.youtube.com/watch?v=S8gZT6Vc9pk, as accessed on 10 March 2016).

66 G Early, WJ Moses, L Wilson \& MR Lefkowitz, "Symposium: Historical roots of Afrocentrism”, Academic Questions, 7(2), 1994, pp. 44-54. 
Afrocentricity also had its critics among feminists who contest that Afrocentrists are feminists who avoid exposing the atrocities that are committed in Africa against women and girls in an attempt to defend Africans from criticism. These critics maintain that many women in Africa are victims of female genital mutilation, sexual harassment, and rape, and that girls are taught to be submissive and boys are encouraged to be sexually aggressive. ${ }^{67}$

Some critics have a problem with the tendency of Afrocentrists to see Africa as the foundation, the basis, and the beginning. Their problem is that the term "Africa" itself is an external term, essentially a Latin name. Before it came into use, Africa was often referred to by outsiders as Ethiopia, again an external term. They caution that when using the terms "Africa" or "Afrocentricity", one needs to keep in mind that these terms do not come from the continent. The term "Afrocentricity", they argue, has no major position in contemporary Africa and essentially comes from the USA. ${ }^{68}$

The central focus of an Afrocentric curriculum for students of African descent is the African experience, whether on the continent or in the diaspora. This, according to some critics, poses another problem. For them, given the broad range of experience of African people, how are these abstract principles reconciled into one solid curriculum? Afrocentricity is based on the premise that somewhere in the universe there is a collective African consciousness. Many scholars contend that there is not a unity of thought across the continent of Africa. There is no single derived African consciousness in the Americas, nor is there one common line of descent or mind of Africans on the continent of Africa ${ }^{69}$ There has never been a collective African spirit or thought or action, despite the effort of the Pan-Africanism movement at the turn of the century and the Negritude movement of the 1930s, 1940s, and 1950s. The premise is therefore questionable, regardless of its promise of bringing clarity of mind, unity of purpose, and collective spirit.

Unity amongst Africans is hampered by a lack of a common language spoken by Africans and class differences. In Africa, as well as in the USA, there is a separation of language and dialect between Africans in the upper, middle, and lower classes. There is no sense of "our struggle" which unifies the varied African minds peopling the world over. There is no single ideology that crosses these

67 NR Allen, "The problem with Afrocentricity...", A book review: An Afrocentric manifesto by Molefe Kete Asente, Polity Press, 2007, p. 1.

68 G Early, WJ Moses, L Wilson \& MR Lefkowitz, "Symposium: Historical roots of Afrocentrism”, Academic Questions, 7(2), 1994, pp.44-54.

69 WE Reed, EJ Lawson \& T Gibbs, "Afrocentrism in the $21^{\text {st }}$ century", The Western Journal of Black Studies, (21)3, 1997, pp. 73-79. 
many boundaries or ethnicity, skin tone, class, religions, and social habits. There are thousands of different languages, thousands of different cultural groups, and regional differences between people from the grasslands, people from the forests, and people from the coast. There are darker skins, brown skins, and lighter skin complexions among Africans. There are rich and poor, educated and uneducated, and Muslim, Christians, and various other religious denominations. ${ }^{70}$

Linked to the issue of language, Afrocentricity is criticised for its recommendation that Swahili should be adopted as an Afrocentric language. The reason for this is that people who were taken to the Americas during the transatlantic slave trade did not speak or even know the language. The same can be said about Africans in Africa where there is a multitude of languages, which raises questions of the acceptability of the recommendation. Some opponents of Afrocentricity have a problem with its approach to knowledge that is Africanised, and prefer what they see as a universal approach to knowledge. ${ }^{71}$

\section{Response to criticism}

For European scholars who register a negative reaction to Afrocentricity, Afrocentrists believe that such detractors do so out of fear, which is revealed on two levels. The first level is that Afrocentricity provides them with no grounds for authority unless they become students of Africans. This fear, they contend, is existential, according to which African scholars might have something to teach whites. ${ }^{72}$ They support this by claiming that much of the disagreement surrounding Afrocentricity emanates from whites wanting to dominate the world and control knowledge; further that they have to admit that the foundations of Western civilisation was laid by non-Europeans. For these defenders of Afrocentricity those who say whites brought forth world civilisation are a bunch of fakers and liars, and claim that world civilisation started in Egypt. ${ }^{73}$ Afrocentric scholars such as Cheikh Anta Diop, John Henrick Clarke, and Chancellor Williams have been criticised for introducing their cultural orientations and correcting the chronological schedule and historical context in which those orientations are rooted in relation to Greek and Roman importance over that of Egypt. Responding to this critique, Afrocentrists maintain that these scholars

70 G Early, WJ Moses, L Wilson, \& MR Lefkowitz, "Symposium: Historical roots of Afrocentrism”, Academic Questions, 7(2), 1994, pp. 44-54.

71 MK Asante, "Afrocentricity and its critics..." (available at http://science.jrank.org/pages/8216/AfrocentricityAfrocentricity-Its-Critics.html, as accessed on 02 April 2016).

72 MK Asante, Afrocentricity: The theory of social change..., p. 6.

73 CC Verharen, Molefi Asante..., The Western Journal of Black Studies. (24)4, 2000, pp. 223-238. 
have been chastised because they somehow illegitimate European history by countering claims about Greek and Roman primacy in rhetorical philosophy. ${ }^{74}$

In response to critics who see Afrocentricity as feminist, Afrocentrists instead view feminism as Eurocentric and therefore negative, seeking to maintain the system of dominance and white privileges that promotes particularism as though it were universal. Contrariwise, Afrocentrists proclaim that Afrocentricity views the male and female as complementary. Moreover, he viewed patriarchy as a Eurocentric phenomenon that gave rise to racism, capitalism, and classism. ${ }^{75}$

In response to their critics, proponents of Afrocentricity name three types of opponents of Afrocentricity and their reasons for opposing it. These are Capitulationists, Europeanised Loyalists, and Maskers. Capitulationists condemn Afrocentricity because they are uncomfortable with themselves and do not believe that Africans should be considered agents. They include amongst black scholars Anthony Appiah and Stanley Crouch,. The functioning element for these critics is self-hatred, accompanied by the belief that these African critics are really nothing but whites in black skin. Their rejection of Afrocentricity is tied to their rejection of themselves. ${ }^{76}$

Europeanised Loyalists include many Marxists and integrationists such as Mary Lefkowitz, Stanley Crouch, and Wilson Moses (staunch critics of Afrocentricity), who believe that blacks can do no good. These critics are strangers to the Afrocentric idea because they have immersed themselves in alien canon of knowledge without knowing African history. The last type, the Maskers, are the critics who are ashamed of Afrocentricity and therefore do all they can to conceal their identities. Their tragedy is that they seek to please the master so they attack Afrocentrists to prove to whites that they are like them. They fear that they may lose their careers. ${ }^{77}$

In spite of criticism against it, Afrocentricity is becoming a popular subject amongst black university students. Academically it has been adopted across several disciplines such as African studies, social work, psychology, sociology, communication, English, political science, history, and anthropology, thereby

74 RL Jackson 1l, "Afrocentricity as metatheory: A dialogic exploration of its principles", RL Jackson \& EB Richardson (eds.), Understanding African American rhetoric: Classical origins to contemporary innovations (New York, Routledge, 2003), pp. 115-129.

75 NR Allen, "The problem with Afrocentricity: Part 1", A book review: An Afrocentric manifesto by Molefe Kete Asente, Polity Press, 2007, p. 1.

76 MK Asante, MK Asante, Afrocentricity: The theory of social change..., p. 7; MK Asante, "Afrocentricity and its critics..." (available at http://science.jrank.org/pages/8216/Afrocentricity-Afrocentricity-Its-Critics.html, as accessed on 2 April 2016).

77 MK Asante, "Afrocentricity and its critics..." (available at http://science.jrank.org/pages/8216/AfrocentricityAfrocentricity-Its-Critics.html, as accessed on 2 April 2016. 
combining elements of philosophy, science, history, and mythology to explain human conditions. ${ }^{78}$ If taught, its teaching can illuminate the distinction between freedom of speech in society and academic freedom in institutions devoted to the dissemination of knowledge. African university (and schools in the case of South Africa) students seeking an identity on traditionally white campuses and schools are attracted to Afrocentricity. An example of this attraction is the demand by students in South Africa for the decolonisation of the curriculum. ${ }^{79}$ Another reason is because of its widespread commercial appeal. Although born and developed in academia, Afrocentricity has become an everyday term. Anything from fabric with an African style to necklaces, hairstyles, and most everything in magazines and clothing and accessories catalogues can be considered Afrocentric. In the USA, for example, ${ }^{80}$

... the term has become a marketplace commodity used to sell almost any item targeted to the African American community. KFC in several urban centers has employees wearing kente cloth designs on uniforms, and new hair care products appeal to the political side of consumers by using the term to signify a true connectedness to an African heritage.

Many blacks find that Afrocentricity has an emotional as well as psychological appeal. This aspect is evident from some people giving their children African names instead of European ones, as has been a norm during colonial times when Africans were given "Christian" names. ${ }^{81}$

Many middle-class Africans believe that the historical role played by people of African descent has been ignored and that Afrocentric scholarship resurrects that history. Some Africans buy into this philosophy and especially those who have succeeded in the white world (middle-class blacks) tend to be more Afrocentric because of their experiences in the workplace and social environment. These middle-class blacks see it as a show of race loyalty and solidarity with other black folks throughout the world. ${ }^{82}$ Some black academicians use it as a mechanism to call attention to differences and to buffer themselves and their colleagues against racism. Therefore Afrocentricity

78 RL Jackson Il, "Afrocentricity as metatheory: A dialogic exploration of its principles", RL Jackson \& EB Richardson (eds.), Understanding African American rhetoric: Classical origins to contemporary innovations (New York, Routledge, 2003), pp. 115-129.

79 K Dlanga, "\#PretoriaGirlsHigh and the myth of multiculturalism”, News 24, 26 August 2016.

80 RL Jackson 1l, "Afrocentricity as metatheory: A dialogic exploration of its principles", RL Jackson \& EB Richardson (eds.), Understanding African American rhetoric: Classical origins to contemporary innovations (New York, Routledge, 2003), pp. 115-129.

81 WE Reed, EJ Lawson \& T Gibbs, "Afrocentrism in the $21^{\text {st }}$ century", The Western Journal of Black Studies, (21)3, 1997, pp. 73-79.

82 MK Asante, "Afrocentricity and its critics..." (available at http://science.jrank.org/pages/8216/AfrocentricityAfrocentricity-Its-Critics.html, as accessed on 2 April 2016); WE Reed, EJ Lawson \& T Gibbs, "Afrocentrism in the $21^{\text {st }}$ century", The Western Journal of Black Studies, (21)3, 1997, pp. 73-79. 
presents an ideological glue or bonding across class and geographical lines.

\section{Conclusion}

It cannot be established with certainty when Afrocentricity as an idea and philosophy emerged. What is clear is that Afrocentricity emerged as a result of African scholars seeking to challenge the Eurocentric perspective of explanation of looking at the world from their point of view. Although it is an antithesis of Eurocentricity, Afrocentricity does not call for the replacement but correction of existing Eurocentric perspectives that seek to exclude or downplay the contributions made by Africans in the development of the world. Afrocentricity therefore can be seen as a cry for the recognition of an African point of view and Africans' role and contribution to world history.

Although a controversial approach, Afrocentricity adds a new dimension by focusing on important areas that were neglected by Eurocentric scholars before, such as the contributions made by Africa and Africans in the development of the world. Academically, in spite of the many problems associated with it, Afrocentricity is adding a new topic to the debates that are ongoing within academic spheres. Despite the criticism levelled against it, the Afrocentric approach can help to solve contemporary problems and demands that are made by African university students, such as calls for the decolonisation of knowledge in academic institutions, especially in South African universities where the call is loud. 